\title{
Wetland Conservation: Challenges Related to Water Law and Farm Policy
}

\author{
Sammy L. King ${ }^{1}$ (i) $\cdot$ Murray K. Laubhan ${ }^{2} \cdot$ Paul Tashjian $^{3} \cdot$ John Vradenburg ${ }^{4} \cdot$ Leigh Fredrickson $^{5}$ \\ Received: 30 October 2020 / Accepted: 15 April 2021 / Published online: 3 May 2021 \\ (C) This is a U.S. government work and not under copyright protection in the U.S.; foreign copyright protection may apply 2021
}

\begin{abstract}
Water is essential for wetland function and sustaining migratory networks for wetland wildlife across broad landscapes. Groundwater declines and surface flow reductions that impact aquatic and wetland organisms are common in the western U.S. and increasingly in the eastern U.S. Agriculture is the largest consumptive water use in the U.S. and understanding economic incentives of water-use practices and the legal context of water rights is foundational to identifying meaningful water solutions that benefit all sectors of society. In this paper, we provide a brief overview of water rights in the U.S. and synthesize the literature to provide a broad overview of how federal farm policy influences water-use decisions. We conclude that the ultimate cause of many water-use conflicts is an inefficient farm economy that is driven by several proximate factors, of which outdated water laws and subsidies that encourage increased water use are among the most important. Development of multi-scale water budgets to assess project impacts and by working more intensively at local watershed and aquifer scales may improve conservation efforts. Finally, detailed analyses to understand the impacts of specific federal policies on agricultural water use may enhance water conservation efforts, facilitate long-term food and water security, and provide greater protection for wetland and aquatic resources.
\end{abstract}

Keywords Wetlands $\cdot$ Water $\cdot$ Agricultural policy $\cdot$ Farm bill $\cdot$ Crop insurance $\cdot$ Irrigation

\section{Introduction}

Wetlands are among the most valuable ecosystems with respect to the provision of ecosystem services (Costanza et al. 2014; Mitsch et al. 2015) and encompass the full range of categories (provisioning, regulating, cultural, and supporting)

Sammy L. King

sking16@1su.edu

1 U.S. Geological Survey, Louisiana Cooperative Fish and Wildlife Research Unit, 124 School of Renewable Natural Resources, Louisiana State University, Baton Rouge, LA 70803, USA

2 Interior Regions 5 and 7, U.S. Fish and Wildlife Service, 1484 NE 80th Street, Stafford, KS 67578, USA

3 Audubon New Mexico, 400 Gold Ave SW, Suite 660, Albuquerque, NM 87102, USA

4 Klamath Basin National Wildlife Refuge Complex, 4009 Hill Road, Tulelake, CA 96134, USA

5 Wetland Management and Educational Services, Inc, Puxico, MO 63960, USA identified in the Millennium Ecosystem Assessment (Reid et al. 2005). Recognition of the value of wetlands to wildlife was a primary consideration in the original development of organized conservation efforts. Federal conservation of wetlands began as early as 1903 with the establishment of Pelican Island National Wildlife Refuge (Reed and Drabelle 1984). Since that time, the Duck Stamp Act, North American Waterfowl Conservation Act, Swampbuster Act, Wetland Reserve Program, Clean Water Act and other federal legislation have resulted in the acquisition, management, and/or protection of wetlands to sustain wildlife habitat and other ecosystem services associated with wetlands. Similarly, many state game and fish agencies and non-governmental organizations have purchased wetlands or protected them with conservation easements for wildlife and biodiversity benefits with many state governments also protecting wetlands through regulatory programs.

The U.S. has expended considerable resources in the protection, conservation, and management of wetlands. However, the unsustainable use of water resources, particularly by agriculture, threatens these efforts and has contributed to wetland loss and disruption of wetland functions by altering the 
volume and timing of surface and/or groundwater inputs (Donnelly et al. 2020; Richter et al. 2020a). Importantly, the impacts of unsustainable water use are not limited to conservation goals. Food, water, energy and climate security are the four resource pillars of global security, prosperity, and equity (Hague 2010). These pillars are clearly interdependent, with availability of water affecting the others. More recently, expanded utilization of water for production of food and energy and to mitigate the direct impacts of a changing climate (Rosa et al. 2017; D'Odorico et al. 2018; Warziniack and Brown 2019) increasingly threaten the availability of water. For example, as of 2014, energy development accounted for about $10 \%$ of consumptive water use in the U.S. and $40 \%$ of water withdrawals; irrigation for corn-based ethanol accounted for about $30 \%$ of all energy withdrawals (Grubert and Sanders 2018). In addition, agriculture accounts for more than $75 \%$ of consumptive water use in the entire U.S. and $85 \%$ in the 17 western states (Richter et al. 2020a) and these estimates do not include green water consumption (Schyns et al. 2019).

Identifying and understanding the root causes of water shortages and conflict are foundational to developing effective conservation measures and ensuring food security, which is a national security issue (Abbott et al. 2018). The U.S. National Intelligence Community Assessment (2012) estimates that global food demands will increase $70 \%$ by 2050 and within 10 years, "the depletion of groundwater supplies in some agricultural areas - due to poor water management—will pose a risk to both national and global food markets." This assessment further noted that improved water management and investments in water-related sectors afford the best solutions for water problems and the greatest benefits would come through improved technology that reduces the amount of water needed for agriculture. Although we agree that improved technology can reduce water needed for agriculture, as explained later in this document, these actions can have unintended negative impacts on wetland conservation efforts and downstream water users due to loss of return flow water to surface and shallow groundwater dependent ecosystems (Arnold 2011; Kendy et al. 2018). Therefore, alternative solutions in addition to technology are necessary to ensure resolution of emerging and anticipated future water conflicts.

Human use is now the largest driver of the hydrologic cycle (Abbott et al. 2019). Richter et al. (2016) noted that one half of all western rivers in the U.S. have greater than $50 \%$ of their flow removed for human uses and one quarter of western rivers have more than $75 \%$ of their flow diverted for consumption, mostly for irrigation. Irrigated cropland in the U.S. has increased by about 3.5 million ha since 1992 (U.S. Department of Agriculture, National Agricultural Statistics Service 2004, 2019a) and the impacts on river and wetland resources are not limited to the arid Western U.S. For example, since 1992 irrigated cropland in Mississippi and Arkansas has increased by $105 \%$ and $80 \%$, respectively (U.S.
Department of Agriculture National Agricultural Statistics Service 2004, 2019a) and has led to over drafting of aquifers and reduced stream flow (Clark et al. 2011; Konikow 2013). Similarly, intensive irrigation and increased urban growth in the Apalachicola-Chattahoochee-Flint River Basins has resulted in interstate water conflicts that have been heard by the U.S. Supreme Court (Rugell and Jackson 2012; Leitman et al. 2017). Declines in the Ogallala aquifer of the High Plains are well documented with aquifer depletion in some areas expected within the next few decades (Scanlon et al. 2012). These declines strongly affect wetland (Wurtsbaugh et al. 2017; Donnelly et al. 2020; Starr and McIntyre 2020) and aquatic systems (Perkin et al. 2017) as well as the farming communities that rely on this water source (Warziniack and Brown 2019).

A high proportion of freshwater aquatic and wetland systems are embedded in landscapes dominated by agriculture and the production of commodities represent the greatest use of water. As a result, achieving a sustainable wetland future, which requires properly functioning hydrology, is intricately linked to agricultural decisions. Therefore, we argue that holistic policy directives that recognize the importance and interconnectedness of agricultural economies and wetland ecosystem services rival technological advancements in achieving a viable, long-term solution to sustainable water use. Developing such directives requires a basic understanding of water law, farm economies, and water use to identify conservation inefficiencies and opportunities. Our objectives are to: 1) Provide a brief overview of agricultural water use and water rights; 2) Discuss factors affecting agricultural decisions and the roles farm policy and global agriculture play in influencing water-use decisions; and 3) Discuss implications of these reviews to conservation efforts. Although allocation of water use to all four resource pillars of global security are important, we focus our review and discussion on agriculture and farm policy since this is the immediate area of most consequential impacts. Our intention is to provide an overview of agricultural water use issues to facilitate thought regarding policy changes that can improve water use behaviors and the conservation of wetland and water resources.

\section{Results}

\section{The Water Management Landscape}

Humans have altered, directly and indirectly, the hydrology of most remaining wetlands in the conterminous U.S. Such alterations have disrupted the ability to reliably provide the suite of desired ecosystem services; therefore, an assortment of infrastructure (e.g., pumps, surface diversions, levees, ditches/canals, water-control structures) is often constructed in various designs to manage hydrology (e.g., timing, depth, and 
duration of flooding) to achieve management objectives. In many cases, surface water infrastructure is shared among diverse user groups (e.g., private farms, public lands). In contrast, the manipulation of groundwater is often isolated to individual entities (e.g., center-pivot irrigation systems, municipal supply, tile drainage); however, impacts of isolated groundwater management activities can affect water available to other users at local and regional scales via multiple mechanisms (e.g., disruption of groundwater flows, aquifer depletion; Scanlon et al. 2012; de Graaf et al. 2019). As a result, regardless of the water source, agricultural production and wetland management are interdependent and water supply shortfalls affect both concurrently. The severity of the impact typically increases as the magnitude of the shortfall increases. Water law bounds the viable resolution of water shortages, which can constrain or enhance conservation opportunities (Richter et al. 2020b). Thus, a basic understanding is foundational for conservationists interested in solving water issues.

\section{Water Law}

In this section we provide a brief summary of issues we consider important to farm policy; water law continues to evolve, and this section does not address the full complexities of water law in the U.S. Throughout the U.S., water is a public resource and, most commonly, states govern the rights to use the resource. Three broad models (summarized below from Getches et al. 2015), enforced variably among states, describe surface water rights in the U.S.: 1) Riparian; 2) Prior appropriation; and 3 ) a hybrid between the two (Dellapenna 2002). The riparian model is common in states east of the Mississippi River and landowners adjacent to streams are granted water rights for "reasonable" use so long as their use does not impair the rights of downstream users. In contrast, the priorappropriation model is common in states west of Kansas City and originated in response to mining interests. Miners often needed to divert water long distances from streams and riparian areas were of little value to them. This model designates seniority based on the filing date for a water right and the requirement that water be put to "beneficial use", which initially was narrowly interpreted to include primarily agricultural, municipal, and industrial uses. Only in the past few decades have states started to recognize environmental uses as beneficial. Seniority of the water right is particularly important because, in the strictest sense, during periods of shortage, fulfillment of senior water rights occurs prior to any junior water rights. Consequently, even though environmental uses may be deemed beneficial, these rights are often junior to traditional uses and often are not implemented on over-allocated streams, particularly in watersheds dominated by intensive agriculture (Smith 2019; Richter et al. 2020b). Hybrid models of water rights take components of the riparian and prior-appropriation models, but which components are incorporated varies among the states using a hybrid approach.

Although states manage water rights, the federal government does have some direct control of water (Gannon 2014; Getches et al. 2015). The Winters Doctrine established that the federal government has the authority to reserve all unappropriated waters necessary to meet the purpose of lands reserved for federal purposes (Winters vs the United States 1908). This doctrine protects water for Native American reservations, national wildlife refuges, and national parks, with the priority date based on the date the reservation or refuge was established and the water quantity based on current and future needs (Cappaert vs United States 1976; Gannon 2014). The federal government also plays a role in ratifying interstate agreements, or compacts, on shared water resources among states, which require adjudication in a judicial proceeding followed by Congressional approval (Getches et al. 2015). A state's legal mandate to fulfill interstate water compacts can result in variable enforcement of existing state water laws or the development of new water laws (e.g., Griggs 2017; Perramond 2020). On the Lower Colorado River, the federal government administers all water rights as the result of the Colorado River Compact (Robison et al. 2014). Numerous federal policies, such as the Clean Water Act and the Endangered Species Act, also can supersede state water rights (i.e., Supremacy Clause).

Groundwater law varies depending on the state (Gannon 2014; Bryan 2015) and according to the National Agricultural Law Center (https://nationalaglawcenter.org/overview/waterlaw/; accessed 01/19/2021 and summarized below) falls within five broad models: Absolute Dominion Rule, Correlative Rights Doctrine, Prior Appropriation Doctrine, Reasonable Use Doctrine, and Restatement (second) of Torts Rule. The Absolute Dominion Rule allows landowners to capture as much groundwater as possible without incurring liability to affected groundwater or surface water users, regardless of the seniority of surface water rights. In addition, groundwater can be sold for off-site use. The Correlative Rights Doctrine apportions water equitably among landowners overlying the aquifer. This doctrine also allows off-site uses, but these uses are a lower priority than on-site uses. Many western states use the PriorAppropriation Doctrine, which gives priority to the first users that divert groundwater for beneficial use; the amount is limited to that which can be put to beneficial use and many states have now replaced this system with a permit system. The Reasonable Use Doctrine allows water to be used for reasonable purposes on the overlying land. It does not allow for off-site use but does interpret "reasonable purpose" broadly. Finally, the Restatement (second) of Torts Rule is essentially a merger of the Absolute Dominion Rule and the Reasonable Use Rule and gives landowners rights of beneficial use of groundwater provided it meets certain restrictions of liability to other groundwater users. 
The diversity of groundwater laws and the limits within each result in some states treating groundwater and surface water as a single resource and others treating them separately (Gannon 2014; Griggs 2017; Owen et al. 2019; https:// nationalaglawcenter.org/overview/water-law/ accessed 01/ 19/2021). The latter approach is in spite of the fact that surface water and groundwater are often, but not always, an interconnected resource (Winter et al. 1998). As such, groundwater pumping can result in reduced river flows as river water recharges the aquifer (de Graaf et al. 2019). In the San Luis Valley of Colorado, the state reduced groundwater pumping due to reduced streamflows, declining groundwater levels, and an inability to fulfill senior surface water rights and meet state obligations set forth in the Rio Grande Interstate Compact (Rio Grande Basin Roundtable 2015). Conversely, the state of Nebraska released water stored in reservoirs used to fulfill senior surface water rights in the Republican River Watershed so the state could meet interstate water compact obligations; they have continued to prioritize groundwater rights over surface water rights (Griggs 2017).

As noted above, owning a water right does not guarantee water delivery. Importantly, water rights are often based on an annual volume, but water shortages often occur because multiple users exercise their water rights during the same time, which creates a demand that is temporally greater than availability. In fact, a large number of streams are over allocated (Richter et al. 2016; but see Owen 2014) and the volume of diverted water consumed is unknown. Furthermore, groundwater pumping, which will generally peak at the same time as surface water irrigation, is unaccounted for and can reduce streamflow. In short, many states do not know how much water their state has, or the volume of water used and/or consumed, which hinders their ability to manage the resource locally and to meet interstate compact requirements (Perramond 2020). This not only negatively affects environmental sustainability, but also affects individual farmers. In 2018, 20,214 farms encompassing 868,860 million ha of farmland reported interruptions in irrigation supplies with $>50 \%$ of the area interrupted by shortages in surface water supplies (U. S. Department of Agriculture National Agricultural Statistics Service 2019a). Although surface water shortages are responsible for most irrigation interruptions, groundwater shortages can also affect irrigation. Texas reported the most land interrupted by groundwater shortages $(59,770$ ha). In emergencies, states can reduce or eliminate water rights with priority generally given to urban demands, followed by agriculture.

In summary, water rights are state rights, with little direct federal control and high variability among states. Furthermore, the basic laws are largely the result of antiquated water management laws and structures developed at a time when ground and surface water resources were considered independent and, for surface water resources, often based on overly optimistic estimates of water availability (Owen et al. 2019; Perramond 2020). Over the past two decades, water law and associated management strategies have been evolving to accommodate our new understanding of water. However, legal frameworks based on dated scientific information still present significant financial and legal challenges (Owen et al. 2019; Perramond 2020) and the evolution of water law has not kept pace with the rapid expansion of irrigation demands, newer societal demands for healthy rivers and regionally diminished water supplies due to climate change. Thus, in spite of long-established water law, water shortages are commonplace in the west and increasingly common in the east.

\section{Factors Affecting Farmers' Decisions}

Water rights legally define the allowable quantity of water use that can occur annually; however, numerous additional factors influence decisions made by farmers regarding the actual quantity used. Potential economic returns, and the risk assumed in pursuing those returns, are major drivers of farming decisions (Blank 2008). In general, the total amount of commodity produced and price per unit for that commodity determine the magnitude of agricultural returns. Assessing these primary drivers requires consideration of numerous other factors operating at multiple, interrelated scales ranging from local to global. Local factors include input costs (e.g., seed, fertilizer, pesticides, fuel, water, transportation, labor) and factors affecting crop choice and productivity such as weather (e.g., temperature, precipitation) and local site conditions (e.g., soils) (Blank 2008). Input costs can vary regionally for the same crop type due to such factors as transportation infrastructure and differences in soils and climate. Other state and federal policies, such as environmental and immigration policy, also can affect input costs. Global factors include the price, demand, and total production of individual commodities (Blank 2008). For example, global diets have shifted to consuming more meat as global economic conditions have improved (Keyzer et al. 2005; Tilman et al. 2011). Meat requires substantially more water than vegetables and grains and these dietary shifts have put tremendous pressure on water resources globally (D'Odorico et al. 2018; Richter et al. 2020a). Richter et al. (2020a) noted that irrigation for cattle feeds is the primary driver of flow depletion in $1 / 3$ of all western watersheds.

A primary method to mitigate production risk is crop irrigation, which has continued to increase and facilitate the transition to more water-intensive crops (Smidt et al. 2019). In 2017, there were 23.5 million ha of irrigated land in the U.S. (U.S. Department of Agriculture National Agricultural Statistics Service 2019b; Fig. 1). Of this area, farms $\geq 404.7$ ha (1000 ac) accounted for $74.7 \%$ (17,547,068 ha) of irrigated area and $13.5 \%$ of total harvested cropland. In 2012, irrigated farmland totaled 22.6 million ha and comprised about $17.7 \%$ of total harvested cropland. In 2012, 
Fig. 1 Total cropland and irrigated land by state (U.S. Department of Agriculture National Agricultural Statistics Service 2019b). Cropland is defined as "areas used for production of adapted crops for harvest" and includes cultivated and non-cultivated crops. "Irrigated land" represents crops grown in the open and pasture

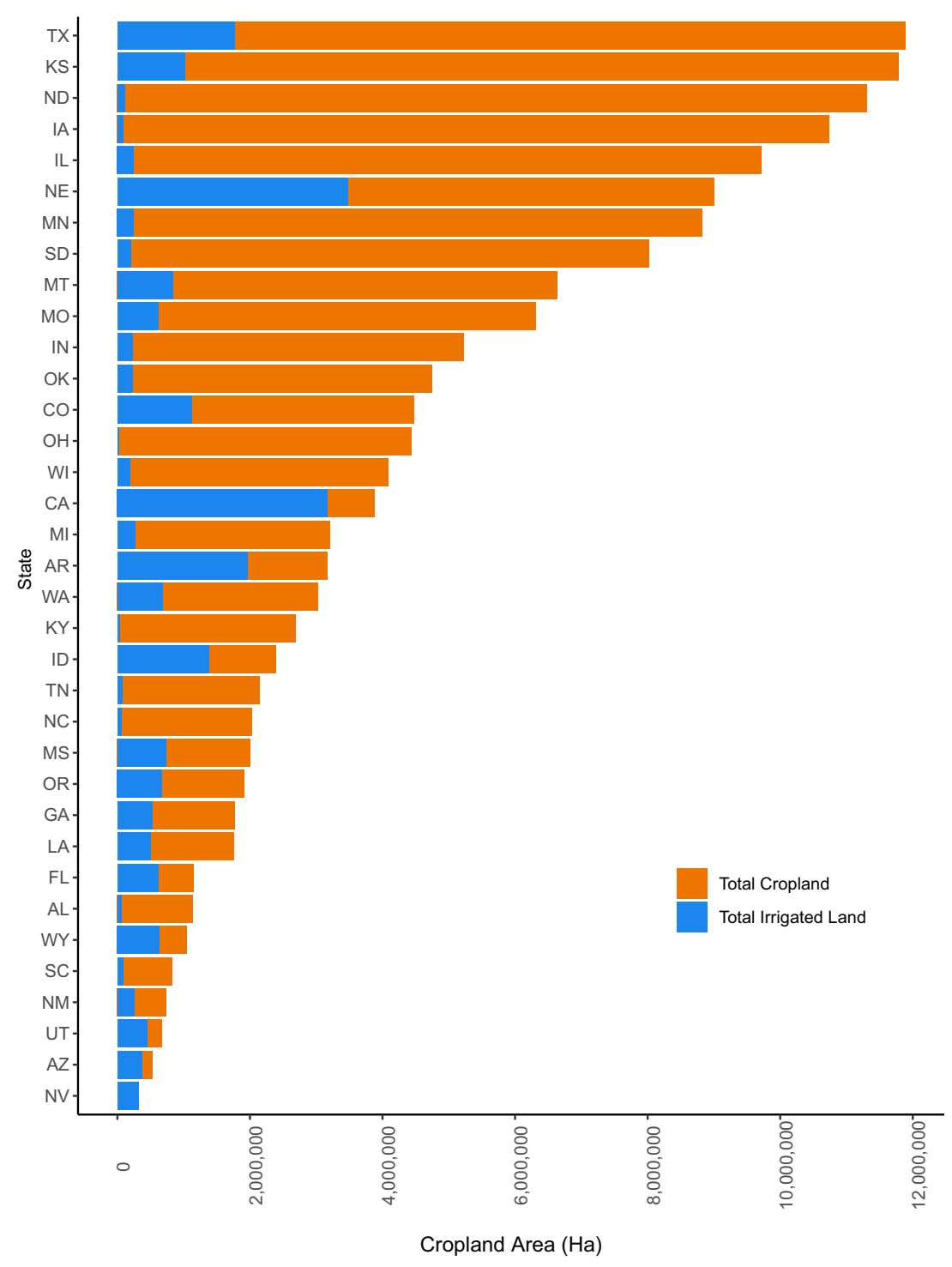

however, irrigated farms accounted for about $50 \%$ of all farm sales (U.S. Department of Agriculture Economic Research Service https:/www.ers.usda.gov/topics/farm-practicesmanagement/irrigation-water-use.aspx accessed 09/14/2020). The predominant irrigated crops in the 17 western states during 2012 were hay and forage crops (24.5\%) and grain corn $(24.5 \%)$, whereas soybeans $(29.6 \%)$ and grain corn $(24$. $3 \%$ ) predominated in the east. Weather accounts for $85 \%$ of crop losses (Olen and Auld 2018) and irrigation capabilities can reduce impacts related to drought and increase production per unit area, as well as increase land value (Zhang et al. 2015; Sampson et al. 2019). For example, the average yield of irrigated and non-irrigated corn in 2017 was 78.1 and 69.9 bushels/ha, respectively (U.S. Department of Agriculture, National Agricultural Statistics Service 2019b). At an average 2017 price of \$3.30/bushel (U.S. Department of Agriculture National Agricultural Statistics Service 2018), this would equate to a difference of $\$ 27.06 /$ ha although this price does not reflect additional input costs of irrigation. Similarly, production of irrigated and non-irrigated alfalfa was 1.7 and 0.9 metric tons/ha dry weight, respectively. Based on an average 2018 price of $\$ 152 /$ metric ton, this would reflect a difference of $\$ 121.60 /$ ha not considering input costs.

The profitability of different crop types also influences farmers' decisions, and increased use of groundwater, subsidized irrigation infrastructure and water costs, and crop insurance have allowed farmers to shift to more profitable crops regardless of their water use requirements (Wichelns 2010; Smidt et al. 2019). Technological advancements (e.g., crop varieties, irrigation) now facilitate the production of many crops across a broader geographic range. As a result, economic conditions, commodity prices, and government policies can result in rapid changes in crop types, as evidenced by the rapid expansion of corn following the ethanol mandate (Welch et al. 2010; Lark et al. 2015) and a more recent increase in hemp (Smith 2018; Sterns 2019). Vegetables and perennial nut 
crops are high value crops, but diseases and climatic requirements can limit where they are grown. In spite of higher water requirements than many other crops, perennial crops often are grown in arid and semi-arid areas and can be highly profitable annually and increase land values (Beene 2019). For example, California produces $80 \%$ of the world's almonds (Almond Board of California 2016) generating \$5.6 billion in 2017 (U.S. Department of Agriculture National Agricultural Statistics Service 2019c), although the high water-use requirements generated widespread criticism during the recent California droughts (Reisman 2019). New Mexico leads the nation in pecan production (37\% of total production) with over $95 \%$ of the acreage in the water-contentious Rio Grande and Pecos River Valleys (O'Leary 1980; Coleman 2018; U.S. Department of Agriculture National Agricultural Statistics Service https://www.nass.usda.gov/Statistics_by_ State/New_Mexico/Publications/Special_Interest_Reports/ 2018-Pecan-CE.pdf; accessed 09/08/2020). A total of 7.2 million ha of alfalfa was grown in the U.S. in 2017, producing 49.3 million metric tons (U. S. Department of Agriculture National Agricultural Statistics Service 2019c) with a value of $\$ 7.5$ billion based on a value of $\$ 152$ per metric ton (prices derived from U.S. Department of Agriculture National Agricultural Statistics Service 2018). Alfalfa also is a high water-use crop and accounts for $20 \%$ of all water used for irrigated crops in the Western U.S. and $37 \%$ of water used for irrigated crops in the Colorado River Basin (Richter et al. 2020a). In general, the more arid regions have higher water use per hectare of cropland, which is both a function of the environment and the choice of crops grown (Fig. 2).

For most crops, farmers are now producing dramatically higher yields per unit area than several decades ago (Andersen et al. 2018) but they are competing in a global market where there is little to no differentiation between products produced in different countries (Blank 2008). Historically, superior technological advantages strongly assisted American farmers in leading the world in agricultural production. Global competitors now, however, rapidly adopt advances in technology. Consequently, economic returns associated with investments in technological advancements have declined dramatically and increased production related to the technology acts to reduce global food prices, which negatively affects individual farm income. For example, corn production is expected to be at record levels in 2020 and soybeans will be at the fourth highest level ever recorded (Abbott 2020). At a regional and national scale, these changes can have dramatic effects on farm income. Sanderson and Frey (2015) noted that corn production in southwest Kansas increased 200-fold from 1958 to 2011 but aggregate personal income in the region remained relatively flat from 1969 to 2011. The latter result contrasted sharply with rapid growth in aggregate personal income in urban areas of Kansas, which rose over $100 \%$ during the same time. At a national scale, farm income, or overall farm economic conditions, show sharply divergent trends. U.S. farm bankruptcies in 2019 were up $20 \%$ from 2018 (595 total filings out of 2,000,000 farms), although still far below record levels (American Farm Bureau Federation 2020; https://www.fb. org/market-intel/the-verdict-is-in-farm-bankruptcies-up-in2019; accessed 02/24/2020). In spite of these bankruptcies, net farm income was slightly higher than the 20-year average, although this was largely a result of government payments to minimize the effects of tariffs on farmers (American Farm Bureau Federation 2020).

\section{Current Economic Condition of U.S. Farms}

Understanding the economic status of farming has important implications for conservation groups working within farming communities. Although there are multiple methods to measure farm economics, it is difficult to accurately describe the national status because conditions vary regionally and locally and even among farmers at a local level. Regardless, the U.S. Department of Agriculture defines farms as "any place from which $\$ 1,000$ or more of agricultural products were produced and sold, or normally would have been sold, during the census year" (U.S. Department of Agriculture National Agricultural Statistics Service 2019b). Thus, farm income (i.e., income derived solely from the farm business) usually is defined in terms of commodity sales. Based on this metric, low agricultural returns from production are commonplace. From 1960 to 2002, farmers in 8 of 10 U.S. regions had an 18.9-30.1\% chance of not breaking even (Blank 2008) and low returns are a continuing trend (Blank 2018). There is also great disparity in farm income relative to farm size with larger farms having the capacity for greater production and, hence, greater income (Table 1). In 2017, for example, 3431 farms with an average size of $1692.8 \mathrm{ha}$ ( $4183 \mathrm{ac}$ ) generated $25 \%$ of all revenue generated from farm products (U.S. Department of Agriculture National Agricultural Statistical Service 2019). However, average farm income can be misleading because government subsidies account for a portion of this income.

On average, government subsidies, largely provided through the Farm Bill, comprise 13.7-46.7\% (\$91,704/yr $\$ 3581 / \mathrm{yr}$ ) of farm-derived income for farms between 4.0 809.4 ha $(10-2000 \mathrm{ac})$ and $16.6 \%(\$ 54,343 / \mathrm{yr})$ of farmderived income on farms $>809.4$ ha $(2000 \mathrm{ac})$ (U.S. Department of Agriculture Agricultural Statistics Service 2019b). Subsidies can take many forms, including direct payments, loans, and crop insurance. Most direct payments go to a few commodity types, including cotton, rice, soybeans, corn, and wheat. Conservation programs, including the Conservation Reserve Program and Wetland Reserve Program, are a form of direct payment and make up about $7 \%$ of the budget for the Agricultural Improvement Act of 
Fig. 2 Gallons per hectare of water used for cropland for selected states. Consumptive water use data are derived from Dieter et al. (2018); cropland acreage is derived from U.S. Department of Agriculture National Agricultural Statistics Service (2019b)

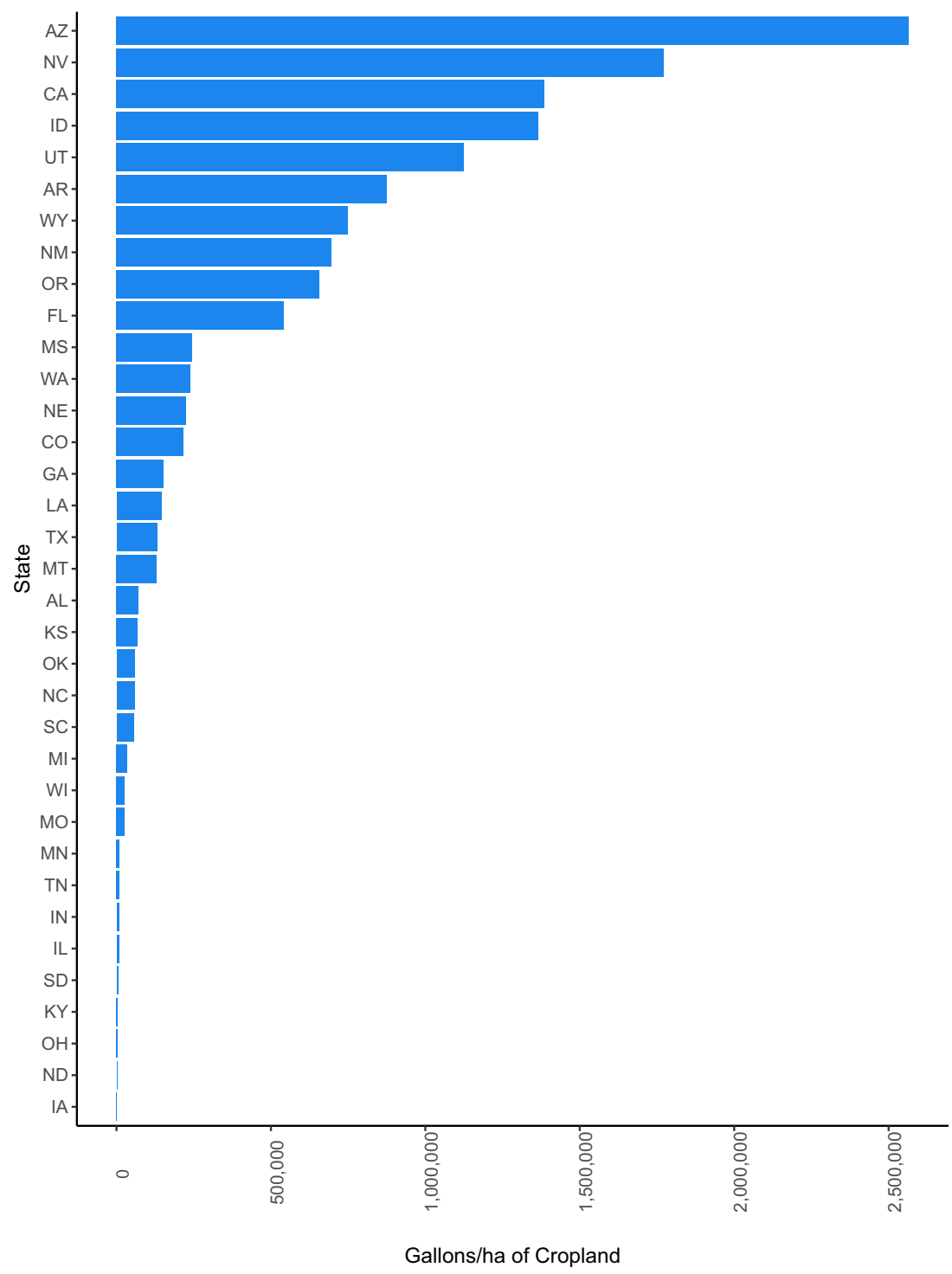

2018 (https://www.ers.usda.gov/agriculture-improvementact-of-2018-highlights-and-implications/ accessed 2/11/ 2020 ). Farms with receipts $<\$ 50,000$ accounted for $54 \%$ of all conservation program dollars and accounted for $93.4 \%$ of farms receiving conservation subsidies (United States Department of Agriculture, National Agricultural Statistics Service 2019b). Only 5.1\% of farms that had any land in irrigation participated in conservation programs; the acreage enrolled in these farms accounted for only $10.8 \%$ of lands enrolled in conservation programs $(977,948$ ha out of 9,009,039 ha enrolled total; United States Department of Agriculture, National Agricultural Statistics Service 2019b).

Farm equity, which is the difference between total assets and total debt, influences loan amounts and interest rates. In 2020, land values accounted for $82.8 \%$ of farm sector assets (U.S. Department of Agriculture Economic Research Service 2020), thus the impacts of changes in land values on capital assets of farms are easily recognized.
Farming is inherently risky and requires substantial upfront investment; thus, the crop insurance program has been popular. Although the program originated in the 1930s, the importance of crop insurance has increased dramatically in the last few Farm Bills. The federal crop insurance program insures more than 117.4 million ha, including more than $80 \%$ of the major field crops area planted in the U.S. (https://www.ers. usda.gov/topics/farm-practices-management/riskmanagement/government-programs-risk.aspx accessed 2/11/ 2020). The latest farm bill also directed the Federal Crop Insurance Corporation to develop options for a variety of other crop insurance coverages including crops on batture lands (i.e., lands inside the levees on the Mississippi River) (https://www.ers.usda.gov/agriculture-improvement-act-of2018-highlights-and-implications/crop-insurance/ accessed 2/11/2020 10:16 am). Crop insurance can take the form of crop yield insurance that addresses yield loss or crop revenue insurance that addresses situations when gross 
Table 1 Selected economic characteristics of U.S. farms by size class for 2017. Discontinuity among classes is due to conversion errors. Data is compiled from United States Department of Agriculture, National Agricultural Statistics Service (2019b)

\begin{tabular}{|c|c|c|c|c|c|c|}
\hline \multicolumn{3}{|l|}{ U.S. Farms } & \multicolumn{2}{|c|}{ Average net cash from farm income } & \multicolumn{2}{|c|}{ Receive government payments } \\
\hline Size (ha) & Number & $(\%)$ & $\begin{array}{l}\text { Average Net Cash } \\
\text { Farm Income of } \\
\text { Operators }(\$)\end{array}$ & $\begin{array}{l}\text { Farms With } \\
\text { Net loss }(\%)\end{array}$ & $\%$ & Average annual (\$) \\
\hline $0.4-3.6$ & 273,325 & 13.4 & 1164 & 76.4 & 4.9 & 3625 \\
\hline $4.0-19.8$ & 583,001 & 28.5 & 6715 & 71.9 & 13.5 & 3139 \\
\hline $20.2-27.9$ & 135,126 & 6.6 & 15,532 & 61.9 & 22.8 & 3699 \\
\hline $28.3-40.1$ & 163,251 & 8.0 & 17,227 & 56.9 & 28.9 & 3963 \\
\hline $40.5-56.3$ & 149,478 & 7.3 & 20,833 & 53.4 & 31.5 & 4709 \\
\hline $56.7-72.4$ & 116,908 & 5.7 & 24,807 & 48.6 & 40.0 & 5500 \\
\hline $72.8-88.6$ & 74,086 & 3.6 & 33,232 & 45.5 & 41.9 & 6192 \\
\hline $89.0-104.8$ & 57,096 & 2.8 & 40,134 & 41.2 & 47.3 & 6648 \\
\hline 105.2-201.9 & 183,835 & 9.0 & 54,257 & 36.8 & 54.7 & 8610 \\
\hline $202.3-404.3$ & 133,321 & 6.5 & 106,307 & 30.3 & 67.2 & 14,603 \\
\hline $404.6-809.0$ & 87,666 & 4.3 & 182,410 & 26.4 & 76.3 & 27,296 \\
\hline$>809.4$ & 85,127 & 4.2 & 327,432 & 25.3 & 75.6 & 54,343 \\
\hline
\end{tabular}

revenue (yield times price) falls below a specified level. The government pays approximately $60 \%$ of the crop insurance premium for farmers and crop insurance companies are paid administrative and operating costs of around 22-24\% of total premiums (https://farm.ewg.org/crop_insurance_analysis.php accessed 01/22/2021) with a targeted return to the companies of $14.5 \%$ annually (Congressional Budget Office; https:// www.cbo.gov/budget-options/56815 accessed 01/22/2021). From 1995 to 2018, the Environmental Working Group reported that principal and interest from farmer crop insurance premiums totaled $\$ 60.5$ billion, but overall government program expenses were $\$ 151.0$ billion (https:// farm.ewg.org/cropinsurance.php accessed 3/27/2020).

An evaluation of farm operator income (i.e., farm and nonfarm income combined) instead of solely farm income creates a more accurate picture. Median annual farm operator income has exceeded median annual U.S. household income every year since 1998 , and was $15 \%$ greater $(\$ 72,481$ vs $\$ 63,179$, respectively) than median annual U.S. household income in 2018 (https:/www.ers.usda.gov/topics/farm-economy/farmhousehold-well-being/income-and-wealth-in-context/). A total of $40.5 \%$ of farms indicated that the occupation of the primary operator of the farm was not farm related (U.S. Department of Agriculture Economic Research Service 2019). This indicates non-farm income makes up a significant portion of farm operator income, particularly those that operate smaller farms (Blank 2008). It is unknown how many of the farms that show negative returns on farm-derived income (Table 1) actually have net profits if non-farm income is considered, but non-farm income likely allows many farmers to sustain wealth by protecting their capital assets, particularly land. However, farmers near urban areas tend to have a competitive advantage in earning non-farm income because the availability of non-farm jobs tends to be lower in isolated rural areas (Blank 2008; Goetz et al. 2018).

Farm wealth also provides a stark contrast to annual farmderived income. In 2016, the most recent data available, the average net worth of an American household was \$692,100 and the median net worth was $\$ 97,300$ (Bricker et al. 2017). In contrast, in 2018, the average net worth of a U.S. farm household was $\$ 862,000$ and commercial farms with greater than $\$ 350,000$ in sales had a median wealth of $\$ 2.8$ million (U. S. Department of Agriculture Economic Research Service 2020; https://www.ers.usda.gov/topics/farm-economy/farmhousehold-well-being/income-and-wealth-in-context/ accessed $08 / 24 / 2020$ ). In 2018 , only $3.2 \%$ of farm households had total wealth less than the median U.S. household wealth and only $2.2 \%$ were considered combined low-income (<median U.S. income for 2018 of $\$ 63,179$ ) and low wealth (< median U.S. household wealth for 2016 of \$97,300). A total of $40.4 \%$ of farms were considered combined low income and high wealth whereas $56.4 \%$ were considered combined high income and high wealth.

\section{Discussion}

In this paper, we have outlined some of the major constructs that underlie challenges of creating sustainable water use in agriculture including the scientific shortcomings and legal constraints of water rights, underlying economic factors that affect farmers' decisions, and the basic economic realities of farming returns. In spite of these challenges, the volume of recent literature documenting the decline of wetlands and aquatic resources, the need to increase agricultural production in the next 30 years, and the plight of small farms indicates 
humans are at a crossroads regarding the use of water to meet societal demands (Perkin et al. 2017; Wurtsbaugh et al. 2017; D'Odorico et al. 2018; Abbott et al. 2019; de Graaf et al. 2019). As the American farm economy continues to adapt to challenges imposed by the globalization of agriculture, Blank (2008) argued that government intervention in this process has slowed progress. Multinational agribusiness firms have thrived under globalized agriculture (Robinson 2018) but continued low commodity prices and subsidy structures have impinged on the ability of small producers, which account for the vast majority of farms, to meet financial obligations (Blank 2008; Bruckner 2016) while simultaneously increasing environmental costs. As a result, farm bankruptcies and consolidation of farmland are inevitable and, ultimately, the agricultural sector of the U.S. economy likely will shrink as investments move to areas of higher potential returns and lower risk (Blank 2008). Blank's (2008) conclusion is based on data indicating all developed countries naturally progress from agricultural-based economies to more advanced economic sectors that eventually produce higher returns than agriculture.

The causes of water-use conflicts often are characterized as differing values between environmentalists and farmers. However, based on our review of the information, we contend that the ultimate cause of many conflicts is an inefficient farm economy that has become overly dependent on unsustainable water use that is facilitated and amplified by outdated water law and over allocation of available water resources (Fig. 3). Historic water law, combined with over allocation of water resources, constrains efforts to control water use whereas federal subsidies provide an economic stimulus to intensify and expand water use. We argue resource conservation and the economic viability of farms are not a dichotomous choice, as both are necessary to sustain our nations' water and food security. Rather, our nation may benefit from a new approach that embraces the combined reality of globalized agriculture, the need for food and water security, and the value of environmental benefits provided by wetland and aquatic systems (Lant et al. 2008). Significant progress in resolving water-use conflicts and the economic well-being of farmers in the U.S. can be achieved through collaborative efforts to revise existing policies that have contributed to the current situation. Success will require individuals comprising all societal sectors to be active participants in developing policy solutions based on factual information and open, honest political discourse. Bosso (2017) noted that the latter can be lacking in some farm policy discussions.

The general argument to improve subsidy structures to reduce water use and environmental impacts also has strong economic arguments that can benefit both farmers and society in general. Blank (2018) argued that the profit problem in American agriculture is related strongly to the structure of agricultural subsidies, which largely are provided to specific commodity groups that are politically connected and lead to over production of certain crops. This results in a high proportion of farmers growing the same crop, regardless of local environmental conditions (e.g., soils, water availability, climate), which drives prices down and limits profits. Weber et al. (2015) argued that the current subsidy structure negatively affects huge sections of rural communities as these subsidies provide little benefit to anyone other than the direct benefits to the farmers. Similarly, Reimer and Weerasooriya (2019) found that the Farm Bill has an overall positive effect on agricultural prices, but the entire effect is due to the nutrition component (i.e., Supplemental Nutrition Assistance Program; SNAP) as farm subsidies actually depress agricultural prices and have an overall net negative impact on U.S. economic output. Furthermore, crop insurance specifically, but also subsidized water and other government subsidies, can lead to irrational but profitable decisions at the farm level that significantly affect water use (Deryugina and Konar 2017) by eliminating or significantly reducing the risk of poor financial decisions and increasing risks taken by producers

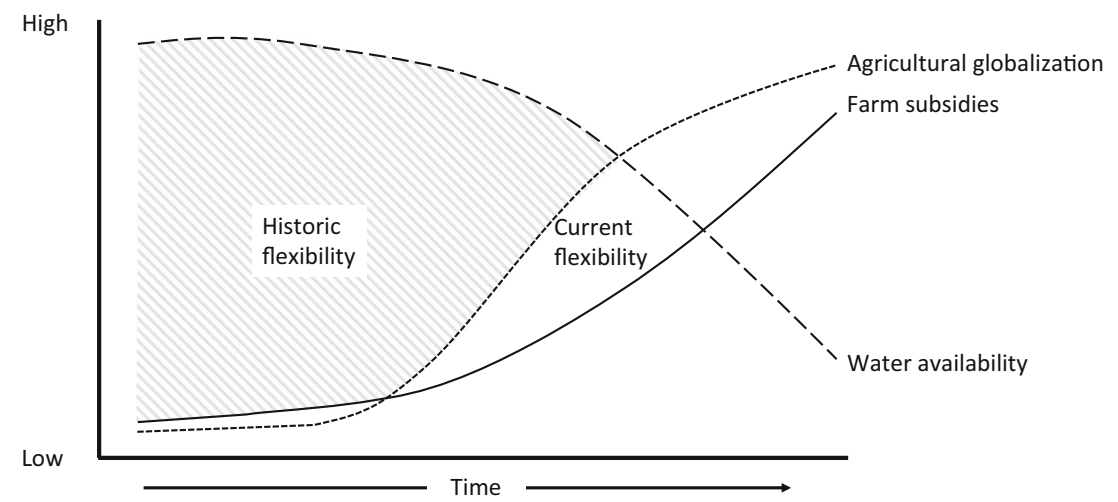

Fig. 3 Conceptual diagram illustrating how the globalization of agriculture and changes in water availability and farm policy combined have constrained flexibility to achieve food and water security, ecosystem services, and farm profits. Solutions will require diverse groups and disciplines working across multiple spatial scales to address local socioeconomic and hydrologic conditions to restore flexibility and ensure a sustainable water future 
(Goodwin and Smith 2013). The crop insurance program has grown exponentially since the 1990s as government subsidy of crop insurance premiums has increased from $26 \%$ in 1990 to about $60 \%$ today (Goodwin and Smith 2013).

Under the current agroeconomic system, small, isolated rural communities, often with little economic diversification, are vulnerable to collapse and their economic revival may require policies other than the Farm Bill (Blank 2008). Crabtree (2016) argued that while the decline of rural America is generally overstated, the Farm Bill through its crop insurance program has facilitated the decline of rural communities by providing financial advantages to large producers and facilitating farm consolidation, an argument also echoed by Bruckner (2016). The roles of globalization and Farm Bill policies on farm consolidation trends are difficult to separate, but both the positive and negative impacts of federal farm programs on rural economies are worthy of further investigation.

A holistic policy approach that directly considers water conservation at multiple spatial scales as a primary outcome may help secure long-term food and water security. A comprehensive assessment of how current farm policy and federal programs related to farm policy affect water use would be highly beneficial (Congressional Budget Office 2006). Several programs directly or indirectly, either purposely or inadvertently, incentivize non-sustainable water use (Mount et al. 2016) including water-use efficiency improvements (Batchelor et al. 2014). Current farm policy also has numerous hidden costs that are substantial, including the maintenance of water infrastructure (Wahl 1989; Holland and Moore 2003; Gardner 1997), mitigation of pervasive nutrient (e.g., nitrogen) and pesticide pollution (Moore et al. 2011; Goulson 2013; Hansen et al. 2019), and healthcare costs associated with pollution impacts (Stayner et al. 2017; Temken et al. 2019). These costs (i.e., negative externalities) often are the assumed responsibility of taxpayers, but rarely mentioned in farm policy literature. Thus, the retail cost of food in the U.S. is not representative of the total costs of production.

Most farm policies to date have focused on farm production income but as noted above, increased production only results in incremental returns. Further, farming contributes only a small percentage to the gross domestic product (GDP) of most states (University of Arkansas Research and Extension, Economic Impact of Agriculture available at: https://economic-impact-ofag.uark.edu/arkansas/ accessed 09/08/2020), even though it accounts for $68-97 \%$ of consumptive water use in western states (Mount et al. 2016; Richter et al. 2020a) (Fig. 4). Obviously, the direct contribution of agriculture to state-level GDP is not a full measure of the value of agriculture to the country. Clearly, however, some of the associated policies tend to facilitate increased agricultural water use but only marginally improve the economic status of small farms and can harm rural communities (Crabtree 2016). Identifying and correcting these issues will be critical to improving water conservation at meaningful scales (e.g., watershed, aquifer) necessary to ensure the collective sustainability of agriculture, natural resources, and communities.

The federal government does not control water rights, but it does affect water use directly and indirectly through a variety of federal policies and incentives. Currently, farm bill programs designed to stabilize or improve farm income largely focus on field-scale practices and conservation programs often focus on biotic components (e.g., grassland and forest plantings) that increase field-scale water savings. However, achieving sustainable water use for all sectors of society will require developing policies that positively influence the effects of farm practices on broader hydrologic processes, including temporal and spatial availability and sustainability of groundwater and surface water resources at multiple scales. Therefore, development of watershed or aquifer water budgets, in addition to field-scale analysis of water use, will be foundational to water conservation approaches (Kendy et al. 2018). A multi-scale evaluation of water budgets could be used to assess potential impacts of all farm policies on the sustainable yield of water and improve existing water use efficiency programs. For example, as noted before, improved efficiency at the field scale often does not result in water savings but actually leads to greater water use as farmers often increase acreage or switch to more water intensive crops (Ward and Pulido-Velazquez 2008; Batchelor et al. 2014; Pfeiffer and Lin 2014). Reducing the development of water infrastructure that enables planting of more water-intensive crops in regions (east or west) where available water currently is, or is projected to be, over allocated could benefit water resources. Similarly, the return to aquifer or river systems of water savings from efficiency improvements could help solidify water conservation gains (Kendy et al. 2018). Interestingly, while this idea has proven effective (Kendy et al. 2018), it would require state governments to adjust water rights and enforce new allocations following efficiency improvements. With such a strategy, coordination among state and federal entities would be required when federal programs are the source of funds used to implement such improvements, as states regulate water rights. This multi-scale understanding of how much water is used and available locally and at broader scales is also necessary to facilitate improved water law (Perramond 2020).

Ultimately, a reduction in water demand, rather than just improved efficiency, is needed to address water shortages. Because water requirements vary dramatically by crop type, the choice of crop planted is one potentially fruitful avenue to explore in reducing water use. Corn, hay (including but not limited to alfalfa), soybeans, cotton, rice and wheat dominate water use of crops in the U.S. (Marston et al. 2018), but locally pecans, almonds, alfalfa, or other crops can dominate local and regional water consumption, which emphasizes the need to develop local solutions to water shortages. For example, 


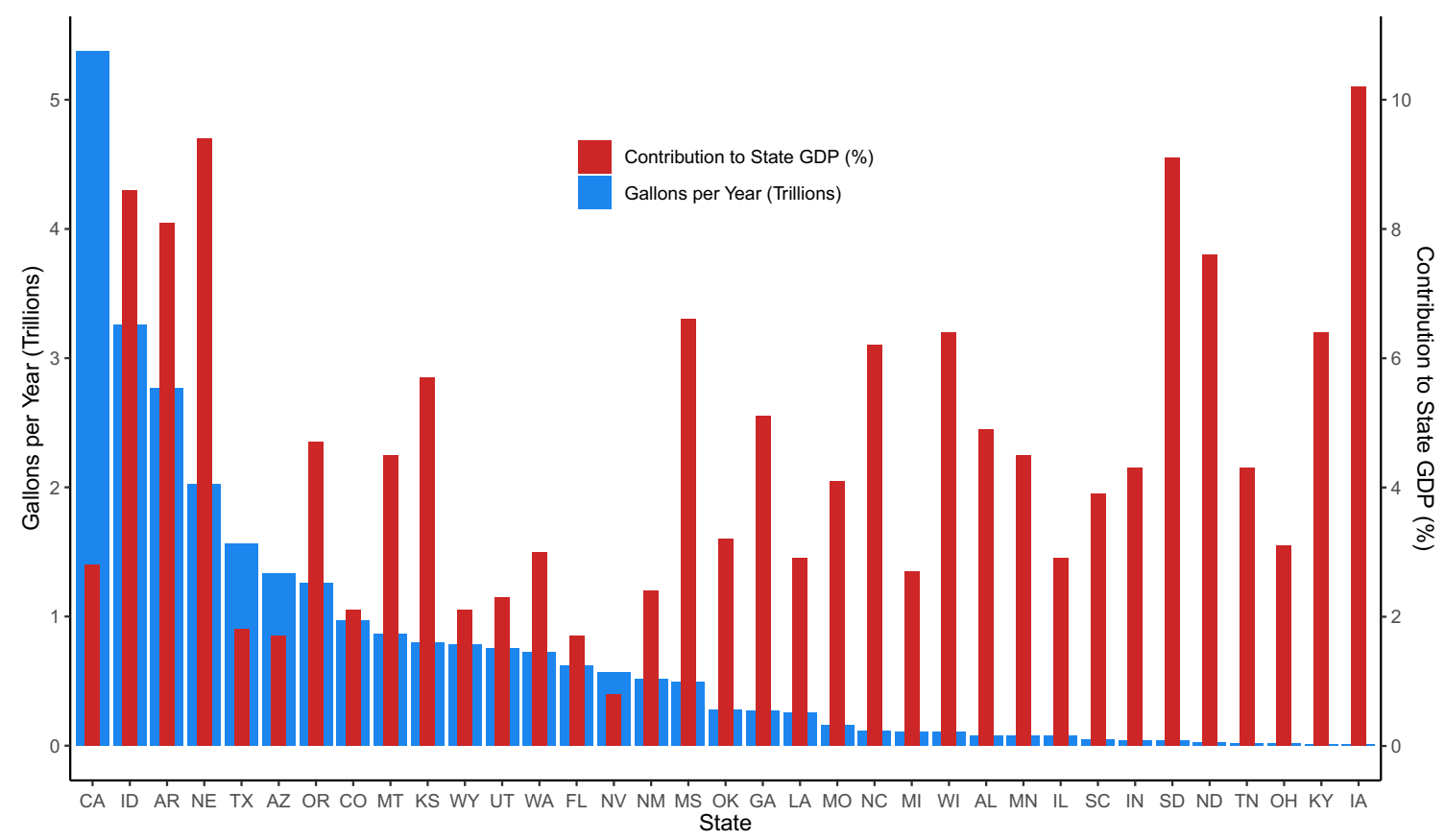

Fig. 4 The percentage of each states gross domestic product (GDP) that is provided by agriculture versus total number of gallons consumed by agriculture in that state. GDP data are derived from the database maintained at: https://economic-impact-of-ag.uark.edu/; consumptive water use of agriculture by state is derived from Dieter et al. (2018)

value of water is difficult to determine because of the paucity of water markets (D'odorico et al. 2020), although water markets can facilitate water rights trade (i.e., water markets) among users and can be beneficial for conservation efforts (Kendy et al. 2018; Richter et al. 2020b). Richter et al. (2020b) and Szeptycki et al. (2015) provide excellent syntheses of the financial costs and administrative and legal challenges of purchasing environmental flow rights. Some progress in securing environmental flows has been made (Kendy et al. 2018), and the ability to lease or purchase water rights can improve water use and provide important environmental benefits (Richter et al. 2020b). Conservation may have a difficult time, however, competing in water markets as long as non-market economic incentives distort the true market value of agriculture.

A more concerted effort to implement farm bill programs in targeted locations also may contribute to substantially increased water savings at meaningful scales. Programs that only seek to improve water-use efficiency are likely too simplistic to meet both water sustainability and wetland/wildlife conservation goals and can lead to greater water use. Rather, approaches necessary to meet sustainable water use goals and simultaneously protect natural wetlands and wetlanddependent wildlife likely will require consideration of numerous water conservation strategies (e.g., alternative crop types, fallowing, improved water-use efficiency) across multiple spatial scales. Currently, government payments on average comprise $20-46 \%$ of farm-related income on farms 4 404 ha in size and $311 \%$ of farm related income on farms costs across the United States. Similarly, the actual economic 
0.4 to 3.6 ha in size (U.S. Department of Agriculture National Agricultural Statistics Service 2019). Although large farms ( $\geq$ $404 \mathrm{ha}$ ) tend to be the most profitable, more than $15 \%$ of farm income is derived from government payments, $>75 \%$ of these farms receive government subsidies (U.S. Department of Agriculture National Agricultural Statistical Service 2019) and these farms control proportionally more irrigated area and presumably use the most water. Therefore, intentionally involving owners of large farms in the delivery of conservation programs may represent the most efficient return of government funds on water savings, although smaller farms may be important users of water in certain watersheds/aquifers. Currently, however, more profitable farms and those with any irrigated land show relatively little interest in conservation programs. It is plausible that the ability to irrigate results in conversion of many marginal farmlands into productive farmlands with greater economic benefit than that provided by existing conservation programs, particularly when combined with the crop insurance safety net.

Although relatively few farms with irrigated acreage receive conservation payments, due to large-scale conversion of wetlands to agriculture in the west, wetlands created or maintained by inefficient use (e.g., flood irrigation) of agricultural water resources are now the most available wetland type for wetland-dependent wildlife (Donnelly et al. 2020). Increased return flows from inefficient flood irrigation also have help sustain aquatic systems in many areas and provide irrigation water for downstream users. Wetland habitat provided by irrigation accounts for $61 \%$ of wetlands in snowmelt watersheds in the western U.S. (Donnelly et al. 2020). This indicates a strong connection between irrigated agriculture and wetland availability, but the same study also indicated that there has been a $47 \%$ reduction in wetlands in these watersheds and only $6 \%$ of land in these watersheds provides wetland benefits.

Temporal patterns of wetland availability in the west often follows regional irrigation schedules driven by requirements of shared crop types, leading to the elimination or reduction of some wetland types and associated resources (Donnelly et al. 2020) thus reducing system resiliency and functional diversity. In the east, reduced flooding associated largely with flood control, but also with drainage and irrigation practices to benefit agriculture (Clark et al. 2011; Konikow 2013), are altering tree species composition in southern forested wetlands (King and Keim 2019) and the temporal availability of the habitat resources provided in these systems (Heitmeyer 2006). While agricultural and managed wetlands are heavily used by migratory birds across the country and they are an important contributor to conservation of wetland wildlife they do not fully replace all the system functions or habitat values of historic wetlands and an over representation of agricultural wetlands reduces system variability and the availability of resources. For example, saline lakes throughout the west provide critical stopover and molting habitat for a diverse assemblage of waterbirds (Jehl 1994; Senner et al. 2018), but the structure and function of these habitats differ dramatically from agricultural wetlands and agricultural water use threatens their future viability. Similarly, large-scale agriculture and urban development drove the loss of vernal pools in California (AECOM 2009) and moist-soil management and flooded agricultural fields fail to replace the values of these pools (King 1998). While many agricultural landscapes may meet the bioenergetic needs of waterfowl, this is a narrow view of wetland landscapes as other critical habitat needs of waterfowl (e.g., thermal cover, refuge, nutrition) and the habitat needs of other wetland-dependent species may not be met in the same landscape. Similarly, intensive agricultural landscapes often disrupt natural hydrologic cycles (Richter et al. 2020a) and assimilation of sediments (Kleiss 1996; Bowen and Johnson 2019) and nutrients (Smith 2019), thereby affecting other ecosystem functions and services. Furthermore, an over reliance on agricultural wetlands at the expense of protection and management of natural wetlands can exert significant negative impacts on many wetland-dependent species, including those that regularly use agricultural sites, to changes in agricultural policy or technological developments, which can occur rapidly and impact wetland density and function at large spatial scales (e.g., Lark et al. 2015).

Farming and wildlife are compatible in certain situations, but it is simply false that status quo farming is (a) necessary to meet global food demands (Blank 2008) (b) is universally beneficial to wetland and wildlife resources (Andrade et al. 2019, Rudel 2020) or (c) that all farmers are struggling to survive financially (Blank 2008). There are obvious environmental and health issues related to our current farming system as well as numerous food production inefficiencies. As of 2013, ethanol production uses about $40 \%$ of corn produced in the U.S., animal foods about $36 \%$, and exports account for most of the rest. Although many animals fed corn eventually will become food, the conversion efficiency for corn is only 3\% to $40 \%$ (Foley 2013). In comparison, growing food exclusively for direct human consumption with the current mix of crops could increase available food calories by as much as $70 \%$ and feed an additional 4 billion people (Cassidy et al. 2013). Current groundwater issues in the High Plains, California, Mississippi Alluvial Valley and elsewhere are cause for concern. Irrigated lands are less susceptible to production losses due to high temperatures (Schauberger et al. 2017); thus, irrigation with groundwater could be an adaptation strategy for future increases in drought frequency and heat waves. However, due to widespread groundwater depletion (Perrone and Jasechko 2017), this strategy will not be a viable future alternative in many agricultural regions. Warziniack and Brown (2019) estimated that in the absence of groundwater mining more than 45.8 million people, primarily in the Southwest, central Great Plains, and southern California, would already be experiencing regular water shortages and the number of people potentially experiencing 
these shortages will grow to 136.2 million people by 2060 . In the Central Valley of California, Pauloo et al. (2020) noted that over 2000 domestic wells failed during the 2012-2016 drought and two to four times that many wells would have failed if the drought had extended another 2-4 years.

Thus, opportunities exist for the conservation community to broaden collaborations with others to develop sustainable water use policies and programs for the benefit of people and wildlife, which must include transparent assessments of longterm systemic impacts on water availability. Purported solutions, such as groundwater mining, interbasin transfers and building irrigation storage reservoirs in remaining wetlands (e.g., Reba et al. 2017), have long-term irreversible consequences for natural resource conservation and often only delay the end of unsustainable water practices rather than solving the problem. Alternatively, reduced consumptive water use with no loss of economic activity is within reach for both the agricultural and non-agricultural sectors (Marston et al. 2020). A refined understanding of how federal policies influence water use at national, regional and local scales and regional water budgets for both surface and groundwater are needed to fully understand macroeconomic farm and water policy effects on local hydrologic and socioeconomic conditions. Subsidy structures and the lack of consumptive water use data at the state scale challenge these efforts. Furthermore, in our experience, discussion of changes in farm or water policy creates angst among farmers and conservationists alike, because livelihoods of both are affected. However, the current approach is not hydrologically sustainable, thereby affecting the long-term, and in some cases, short-term (Scanlon et al. 2012), economic security of farming and the future of wetland and water resources.

\section{Conclusions}

We do not purport to have the single solution to agriculture and water conflicts, nor does one likely exist considering the variability and complexity of water law and socioeconomics. However, current water use patterns are not sustainable in the western and at least parts of the eastern U.S. Existing conservation programs, such as the Conservation Reserve Program and the Wetland Reserve Program, help by removing marginal lands from production, but may be ineffective in affecting water conservation because these programs receive little participation from larger, more profitable farms that have irrigation capabilities. Furthermore, many water conservation strategies improve water use efficiency but reduce water availability at the watershed scale.

Much of this article has focused on the Western U.S. but groundwater declines and increased emphasis on irrigation are also common in the east and impacts to groundwater, surface water, and wetlands are emerging in eastern systems such as the Mississippi River Alluvial Valley and the Flint River
Basin in Georgia (Clark et al. 2011; Rugel et al. 2012; Konikow 2013; Caccese and Fowler 2015; King and Keim 2019). Water law constrains solutions within the current subsidy-driven model, but federal incentives through farm policy (including but not exclusive to the farm bill), development and maintenance of water storage and delivery mechanisms, and other federal programs provide the economic incentive underlying non-sustainable irrigation practices. Therefore, we argue that the greatest opportunity to achieve meaningful water conservation may lie within strategic reform of policy initiatives that distort agricultural economies and encourage unsustainable water use. While potential impacts to the agricultural community are unavoidable with changes in federal programs, many agricultural producers are struggling under the current model ( $42 \%$ are low income), impacts to water resources are pervasive and, in many cases, irreversible and irrigated agricultural production will be significantly curtailed in many areas as water levels decline. Thus, changes in agricultural practices are coming regardless of whether modifications of federal interventions occur. However, instituting targeted change, rather than following status quo, provides a fleeting opportunity to minimize the collective impacts to wetland and aquatic resources and local agricultural communities. We urge conservationists to consider the full impacts of Farm Bill Programs on wetland and aquatic resources and not just limit their views to the values provided by affiliated conservation programs. Furthermore, we urge a comprehensive interdisciplinary review of federal policy impacts on water, wetland, and aquatic resources to help guide policy discussions.

Acknowledgments The findings and conclusions in this article are those of the authors and do not necessarily represent the views of the U.S. Fish and Wildlife Service. We thank D. Fowler, J. Bergan, K. McKnight, K. Ribbeck, P. Donnelly, C. Lant, J. Schmid, S. Megdal, C. Foley, A. Ogelsby and two anonymous reviewers for constructive comments and discussions.

Availability of Data and Material Data are all derived from public sources.

Code Availability N/A

Author's Contributions Writing SK - 60\%; ML- 20\%; PT - 10\%; JV$5 \%$; LF $-5 \%$.

\section{Declarations}

Ethics Approval N/A

Consent for Publication This manuscript is for exclusive publication in Wetlands.

Consent to Participate N/A (not sure what is being asked).

Conflicts of Interests/Competing Interests None. 
Open Access This article is licensed under a Creative Commons Attribution 4.0 International License, which permits use, sharing, adaptation, distribution and reproduction in any medium or format, as long as you give appropriate credit to the original author(s) and the source, provide a link to the Creative Commons licence, and indicate if changes were made. The images or other third party material in this article are included in the article's Creative Commons licence, unless indicated otherwise in a credit line to the material. If material is not included in the article's Creative Commons licence and your intended use is not permitted by statutory regulation or exceeds the permitted use, you will need to obtain permission directly from the copyright holder. To view a copy of this licence, visit http://creativecommons.org/licenses/by/4.0/.

\section{References}

Abbott BW, Bishop K, Zarnetske JP, Minaudo C, Chapin FS III, Krause S, Hannah DM, Conner L, Ellison D, Godsey SE, Plont S, Marçais J, Kolbe T, Huebner A, Frei RJ, Hampton T, Gu S, Buhman M, Sayedi SS, Ursache O, Chapin M, Henderson KD, Pinay G (2019) Human domination of the global water cycle absent from depictions and perceptions. Nature Geoscience 12:533-540

Abbott, C. (2020) The largest corn crop ever is coming, USDA says. Successful Farming. February 21, 2020. https://www.agriculture. $\mathrm{com} /$ news/crops/the-largest-corn-crop-ever-is-coming-usda-says (accessed 2/24/2020)

Abbott M, Bazilian M, Egel D, Willis HH (2018) Examining the foodenergy-water and conflict nexus. Current Opinion Chem Eng 18:55-60

AECOM (2009) Loss of Central Valley vernal pools: land conversion, mitigation requirements, and preserve effectiveness. https://www. vernalpools.org/vpreports/VP\%20Summary\%20Report_Final.pdf (accessed 08/27/2020)

Almond Board of California (2016) California almond industry facts. https://www.almonds.com/sites/default/files/2016_almond_ industry_factsheet.pdf (accessed on 04/02/2020)

American Farm Bureau Federation (2020) The verdict is in: farm bankruptcies up in 2019. January 29, 2020. https:/www.fb.org/marketintel/the-verdict-is-in-farm-bankruptcies-up-in-2019 (accessed 02/ 24/2020)

Andersen MA, Alston JM, Pardey PG, Smith A (2018) A century of U.S. farm productivity growth: a surge then a slowdown. Am J Agri Econ 100:1072-1090

Andrade C, Villers A, Balent G, Bar-Hen A, Chadoeuf J, Cylly D, Cluzeau D, Fried G, Guillocheau S, Pillon O, Porcher E, Tressou J, Yamada O, Lenne N, Jullien J, Monestiez P (2019) A real-world implantation of a nationwide, long-term monitoring program to assess the impact of agrochemicals and agricultural practices on biodiversity. Ecol Evol 2020(00):1-23

Arnold LR (2011) Estimates of deep-percolation return flow beneath a flood- and a sprinkler-irrigated site in Weld County, Colorado, 2008-2009: U.S. Geological Survey Scientific Investigations Report 2011-5001

Batchelor C, Reddy VR, Linstead C, Dhar M, Roy S, May R (2014) Do water-saving technologies improve environmental flows? J Hydrol 518:140-149. https://doi.org/10.1016/j.jhydrol.2013.11.063

Beene DR (2019) Adjudication and the adaptive capacity of pecan farmers in the lower Rio Grande. M.S. Thesis, University of New Mexico, Albuquerque

Blank SC (2008) The economics of American agriculture: evolution and global development. Routledge, London
Blank SC (2018) The profit problem of American agriculture: what we have learned with the perspective of time. Choices 33(3):1-7

Bosso C (2017) Framing the farm bill: interests, ideology and the agricultural act of 2014. University Press of Kansas, Lawrence

Bricker, J., Dettling, L.J., Henriques, A., Hsu, J.W., Jacobs, L., Moore, K.B., Pack, S., Sabelhaus, J., Thompson, J., Windle, R.A. (2017) Changes in U.S. family finances from 2013 to 2016: evidence from the survey of consumer finances. Federal Reserve Bulletin 103, No. 3. https://www.federalreserve.gov/publications/2017-Septemberchanges-in-us-family-finances-from-2013-to-2016.htm (accessed $09 / 17 / 2020)$

Bruckner T (2016) Agricultural subsidies and farm consolidation. Am J Econ Sociol 75:623-648

Bryan, M. (2015) At the end of the day: are the West's general stream adjudications relevant to modern water rights administration. 15 Wyoming law review 461

Caccese RT, Fowler LB (2015) Reasonable use?: the challenges of transboundary groundwater regulation in the eastern United States. J Am Water Res Assoc 56:379-386

Cappaert v. United States, 426 U.S. 128 (1976)

Cassidy ES, West PC, Gerber JS, Foley JA (2013) Redefining agricultural yields: from tonnes to people nourished per hectare. Environ Res Lett 8:034015

Clark, B, Hart, R.M., Gurdak, J.J. (2011) Groundwater availability of the Mississippi Embayment. USGS Professional Paper 1785. Reston, Virginia

Coleman M (2018) Supreme court hears NM-Texas water dispute. Albuquerque Journal, January 9. Available at: https://www. abqjournal.com/1116605/supreme-court-hears-nmtexas-waterdispute.html. (accessed 04/02/2020)

Congressional Budget Office (2006) How federal policies affect the allocation of water. Congress of the United States, Congressional Budget Office, Paper 2589. Available at: https://www.cbo.gov/ sites/default/files/109th-congress-2005-2006/reports/08-07waterallocation.pdf. (accessed 09/17/2020)

Costanza R, DeGroot R, Sutton P, Van Der Ploeg S, Anderson SJ, Kubiszewski I, Farber S, Turner RK (2014) Changes in the global value of ecosystem services. Global Environ Change 26:152-158

Crabtree J (2016) A different path for rural America. Am J Econ Sociol 75:605-622

de Graaf IEM, Gleeson T, van Beek LPH, Sutanudjaja EH, Bierkens MFP (2019) Environmental flow limits to global groundwater pumping. Nature 574:90-94

Dellapenna JW (2002) The law of water allocation in the southeastern states at the opening of the twenty-first century. Univ Arkansas Little Rock Law Rev 25:9-87

Deryugina T, Konar M (2017) Impacts of crop insurance on water withdrawals for irrigation. Adv Water Res 110:437-444

Dieter CA, Maupin MA, Caldwell RR, Harris MA, Ivahnenko TI, Lovelace JK, Barber NI, Linsey KS (2018) Estimated use of water in the United States in 2015: U.S. Geological Survey Circular 1441, 65 p [Supersedes USGS Open-File Report 2017-1131]

D’Odorico P, Davis KF, Rosa L, Carr JA, Chiarelli D, Dell'Angelo J, Gephart J, MacDonald GK, Seekell DA, Suweis S, Rulli MC (2018) The global food-energy-water nexus. Rev Geophys 56:456-531

D'Odorico P, Chiarelli DD, Rosa L, Bini A, Zilberman D (2020) The global value of water in agriculture. Proc Natl Acad Sci 117:21985-21993

Donnelly JP, King SL, Silverman NL, Collins DP, Carrera-Gonzalez EM, Lafón-Terrazas A, Moore JN (2020) Climate and human water use diminish wetland networks supporting continental waterbird migration. Global Change Biol 26:2042-2059 
Foley J (2013) It's time to rethink America's corn system. Scientific American. https:/www.scientificamerican.com/article/time-torethink-corn/ (accessed 08/27/2020)

Gannon CG (2014) Legal protection for groundwater-dependent ecosystems. Michigan J Environ Administrative Law 4:183-212

Gardner BD (1997) Some implications of federal grazing, timber, irrigation, and recreation subsidies. Choices 12(3):9-14

Getches DH, Zellmer SB, Amos A (2015) Water law in a nutshell, 5th edn. West Academic Publishing, St. Paul

Goetz SJ, Partridge MD, Stephens HM (2018) The economic status of rural America in the president trump era and beyond. Appl Econ Perspect Policy 40:97-118

Goodwin BK, Smith VH (2013) What harm is done by subsidizing crop insurance? Am J Agri Econ 95:489-497

Goulson D (2013) An overview of the environmental risks posed by neonicotinoid insecticides. Journal of Applied Ecology 50:977-987

Griggs BW (2017) The political cultures of irrigation and the proxy battles of interstate water litigation. Natural Res J 57:1-73

Grubert E, Sanders KT (2018) Water use in the United States energy system: a national assessment and unit process inventory of water consumption and withdrawals. Environ Sci Technol 52:6695-6703

Hague W (2010) Russell C. Luffingwell Lecture: The Diplomacy of Climate Change. Presented to Council on Foreign Relations. https:/www.cfr.org/event/russell-c-leffingwell-lecture-diplomacyclimate-change-0 (accessed 02/19/2020)

Hansen SP, Messer TL, Mittelstet AR (2019) Mitigating the risk of atrazine exposure: identifying hot spots and hot times in surface waters across Nebraska, USA. J Environ Manag 250:109424

Heitmeyer ME (2006) The importance of winter floods to mallards in the Mississippi Alluvial Valley. J Wildlife Manag 70:101-110

Holland SP, Moore MR (2003) Cadillac Desert revisited: property rights, public policy, and water-resource depletion. J Environ Econ Manag 46:131-155

Jehl JR Jr (1994) Changes in saline and alkaline lake avifaunas in western North America in the past 150 years. Stud Avian Biol 15:258-272

Johnson R, Cody BA (2015) California agricultural production and irrigated water use. Congressional Research Service 7-5700. R44093. https://fas.org/sgp/crs/misc/R44093.pdf (accessed 09/17/2020)

Kendy E, Aylward B, Ziemer LS, Richter BD, Colby BG, Grantham TE, Sanchez L, Dicharry WB, Powell EM, Martin S, Culp PW, Szeptycki LF, Kappel CV (2018) Water transactions for streamflow restoration, water supply reliability, and rural economic vitality in the Western United States. J Am Water Res Assoc 54:487-504

Keyzer MA, Merbis MD, Pavel IFPW, van Wesenbeeck CFA (2005) Diet shifts towards meat and the effects on cereal use: can we feed the animals in 2030? Ecol Econ 55:187-202

King JL (1998) Loss of diversity as a consequence of habitat destruction in California vernal pools. In: Witham CW, Bauder ET, Belk D, Ferren WR Jr, Ornduff R (eds) Ecology, conservation, and Management of Vernal Pool Ecosystems - proceedings from a 1996 conference. California Native Plant Society, Sacramento, pp 119-123

King SL, Keim RF (2019) Hydrological modifications challenge bottomland hardwood management. J Forestry 117:504-514

Kleiss BA (1996) Sediment retention in a bottomland hardwood wetland in Eastern Arkansas. Wetlands 16:321-333

Konikow LF (2013) Groundwater depletion in the United States (19002008). U.S. Geological survey, scientific investigations report 2013-5079. Reston, Virginia

Lant CL, Ruhl JB, Kraft SE (2008) The tragedy of ecosystem services. BioScience 58:969-974

Lark TJ, Salmon JM, Gibbs HK (2015) Cropland expansion outpaces agricultural and biofuel policies in the United States. Environ Res Lett 10:044003
Leitman SF, Kider GA, Wright DL (2017) Simulating system-wide effects of reducing irrigation withdrawals in a disputed river basin. River Res Appl 33:1345-1353

Lustgarten, A., Sadasivam, N. (2015) Holy crop: How federal dollars are financing the water crisis in the west. https://projects.propublica.org/ killing-the-colorado/story/arizona-cotton-drought-crisis (accessed 08/27/2020)

Mall NK, Herman JD (2019) Water shortage risks from perennial crop expansion in California's Central Valley. Environ Res Lett 14: 104014

Marston L, Ao Y, Konar M, Mekonnen MM, Hoekstra AY (2018) Highresolution water footprints of production of the United States. Water Res Research 54:2288-2316

Marston LT, Lamsal G, Ancona ZH, Caldwell P, Richter BD, Ruddell BL, Rushforth RR, Davis KF (2020) Reducing water scarcity by improving water productivity in the United States. Environ Res Lett 15:094033

Mitsch JM, Bernal B, Hernandez ME (2015) Ecosystem services of wetlands. Intl J Biodivers Sci Ecosyst Services Manag 11:1-4

Moore E, Matalon E, Balazs C, Clary J, Firestone L, De Anda S, Guzman M (2011) The human costs of nitrate-contaminated drinking water in the San Joaquin Valley. Pacific Institute, Oakland, California. https://pacinst.org/wp-content/uploads/2011/03/nitrate_ contamination3.pdf. (accessed 02/18/2020)

Mount J, Hanak E, Chappelle C, Colby B, Frank R, Gartrell G, Gray B, Kenney D, Lund J, Moyle P, Szeptycki L (2016) Improving the federal response to western drought: five areas for reform. Public Policy Institute of California. San Francisco. https://www.ppic.org/ content/pubs/report/R_216JMR.pdf (accessed 9/17/2020)

O'Leary, M.C. (1980) Texas v. New Mexico: the Pecos River compact litigation. Natural Res J 20:395-410 https://digitalrepository.unm. edu/nrj/vol20/iss2/15/ (accessed 09/17/2020)

Olen B, Auld S (2018) A roadmap for assessing relative risks for agricultural production. Choices 33:1-6

Owen D (2014) Overallocation, conflict, and water transfers. Environ Res Lett 9(9):091005

Owen D, Cantor A, Nylen NG, Harter T, Kiparsky M (2019) California groundwater management, science-policy interfaces, and the legacies of artificial legal distinctions. Environ Res Lett 14:045016

Pauloo RA, Escriva-Bou A, Dahlke H, Fencl A, Guillon H, Fogg GE (2020) Domestic well vulnerability to drought duration and unsustainable groundwater management in California's Central Valley. Environ Res Lett 15:044010

Perkin JS, Gido KB, Falkec JA, Fausch KD, Crockette H, Johnson ER, Sandersong J (2017) Groundwater declines are linked to changes in Great Plains stream fish assemblages. Proceedings of the national. Acad Sci USA 114(28):7373-7378

Perramond EP (2020) Water rights, river compacts, and legal-policy stationarity in the American West. Environ Res Lett 15:025002

Perrone D, Jasechko S (2017) Dry groundwater wells in the western United States. Environ Res Lett 12:104002

Pfeiffer, L, Lin, C.-Y.C. (2014) Does efficient irrigation technology lead to reduced groundwater extraction? Empirical evidence. J Environ Econ Manag 67:189-208

Reba ML, Massey JH, Adviento-Borbe MA, Leslie D, Yaeger MA, Anders M, Farris J (2017) Aquifer depletion in the lower Mississippi River basin: challenges and solutions. J Contemporary Water Res Education 162:128-139

Reed NP, Drabelle D (1984) The United States fish and wildlife service. Westview Press, Boulder

Reid W, Mooney H, Cropper A, Capistrano D, Carpenter S, Chopra K (2005) Millennium ecosystem assessment. Ecosystems and human well-being: synthesis. Island Press, Washington, DC 
Reimer JJ, Weerasooriya S (2019) Macroeconomic impacts of U.S. farm and nutrition programs. J Agric Resour Econ 44:624-645

Reisman E (2019) The great almond debate: a subtle double movement in California water. Geoforum 104:137-146

Richter BD, Powell EM, Lystash T, Faggert M (2016) Protection and restoration of freshwater ecosystems, in. K. a Miller, a.F. hamlet, D.S. Kenney, and K.T. Redmond, eds. Water policy and planning in a variable and changing climate. CRC press, Boca Raton, FL, pp 81-105

Richter BD, Andrews S, Dahlinghaus R, Freckmann G, Ganis S, Green J, Hardman I, Palmer M, Shalvey J (2020b) Buy me a river: purchasing water rights to restore river flows in the Western USA. J Am Water Res Assoc 56:1-15

Richter BD, Bartak D, Caldwell P, Davis KF, Debaere P, Hoekstra AY, Li T, Marston L, McManamay R, Mekonnen MM, Ruddell BI, Rushforth RR, Troy TJ (2020a) Water scarcity and fish imperilment driven by beef production. Nature Sustain 3:319-328

Rio Grande Basin Roundtable (2015) Rio Grande Basin implementation plan. https://www.colorado.gov/pacific/sites/default/files/rgbipfor\%20web\%20viewing.pdf. (accessed 07/28/2020)

Robinson GM (2018) Globalization of agriculture. Ann Rev Resource Econ 10:133-160

Robison J, Bratrschovsky K, Latcham J, Morris E, Palmer V, Villanueva A (2014) Challenge and response in the Colorado River Basin. Water Policy 16(S1):12-57

Rosa L, Rulli MC, Davis KF, D’Odorico P (2017) The water-energy nexus of hydraulic fracturing: a global hydrologic analysis for shale oil and gas extraction. Earths Future 6:745-756

Rudel TK (2020) The variable paths to sustainable intensification in agriculture. Regional Environ Change 20:126

Rugell K, Jackson CR (2012) Effects of irrigation withdrawals on streamflows in a karst environment: lower Flint River basin, Georgia, USA. Hydrol Process 26:523-534

Sampson GS, Hendricks NP, Taylor MR (2019) Land market valuation of groundwater. Res Energy Econ 58:101120

Sanderson MR, Frey RS (2015) Structural impediments to sustainable groundwater management in the High Plains aquifer of western Kansas. Agri Human Values 32:401-417

Scanlon BR, Faunt CC, Longuevergne L, Reedy RC, Alley WM, McGuire VL, McMahon PB (2012) Groundwater depletion and sustainability of irrigation in the US High Plains and Central Valley. Proc Natl Acad Sci USA 109:9320-9325

Schauberger B, Archontoulis S, Arneth A, Balkovic J, Ciais P, Deryng D, Elliott J, Folberth C, Khabarov N, Müller C, Pugh TAM, Rolinski S, Schaphoff S, Schmid E, Wang X, Schlenker W, Frieler K (2017) Consistent negative response of US crops to high temperatures in observations and crop models. Nature Commun 8:13931

Schyns JF, Hoekstra AY, Booij MJ, Hogeboom RJ, Mekonnen MM (2019) Limit's to the world's green water resources for food, feed, fiber, timber, and bionenergy. Proc Natl Acad Sci 116:4893-4898

Senner NR, Moore JN, Seager ST, Dougill S, Kreuz K, Senner SE (2018) A salt lake under stress: relationships among birds, water levels, and invertebrates at a Great Basin saline lake. Biol Conserv 220:320-329

Smidt SJ, Kendall AD, Hyndman DW (2019) Increased dependence on irrigated crop production across the CONUS (1945-2015). Water $11: 1458$

Smith, J. (2019) Denver developer, former governor make \$118M play for San Luis Valley water. Water education Colorado. https://www. watereducationcolorado.org/fresh-water-news/denver-developerformer-governor-make-118m-play-for-san-luis-valley-water/ (accessed 02/26/2020)

Smith, V.H. (2018) Hemp and CBD now qualify for one of the most lucrative - and wasteful - government subsidies. MarketWatch https://www.marketwatch.com/story/hemp-and-cbd-now-qualify- for-one-of-the-most-lucrative-and-wasteful-government-subsidies2018-12-19 (accessed 03/27/2020)

Starr SM, McIntyre NE (2020) Land-cover changes and influences on playa wetland inundation on the southern High Plains. J Arid Environ 175:104096

Stayner LT, Almberg K, Jones R, Graber J, Pedersen M, Turyk M (2017) Atrazine and nitrate in drinking water and the risk of preterm delivery and low birth weight in four Midwestern states. Environ Res 152:294-303

Sterns JA (2019) Is the emerging U.S. hemp industry yet another boom bust market for U.S. farmers? Choices 34:1-8

Szeptycki LF, Forgie J, Hook E, Lorick K Womble P (2015) Environmental water rights transfers: a review of state laws. Water in the West, Stanford University, California

Temken A, Evans S, Manidis T, Campbell C, Naidenko OV (2019) Exposure-based assessment and economic valuation of adverse birth outcomes and cancer risk due to nitrate in United States drinking water. Environ Res 176:108442

Tilman D, Balzer C, Hill J, Befort BL (2011) Global food demand and the sustainable intensification of agriculture. Proc Natl Acad Sci USA 108(50):20260-20264

United States Department of Agriculture Economic Research Service (2019) Irrigation and water use. https://www.ers.usda.gov/topics/ farm-practices-management/irrigation-water-use.aspx\#importance. (accessed 04/02/2020)

United States Department of Agriculture, Economic Research Service (2020) Income and wealth in context. https://www.ers.usda.gov/ topics/farm-economy/farm-household-well-being/income-andwealth-in-context/. (accessed 08/24/2020)

United States Department of Agriculture National Agricultural Statistics Service (2004) 2002 Census of Agriculture. Farm and Ranch Irrigation Survey 2003. Volume 3 Special Studies Part 1. AC-02-SS-1

United States Department of Agriculture National Agricultural Statistics Service (2018) Crop values 2017 summary. https://www.nass.usda. gov/Publications/Todays_Reports/reports/cpv10218.pdf. (accessed 08/28/2020)

United States Department of Agriculture National Agricultural Statistics Service (2019a) 2017 Census of Agriculture: 2018 Irrigation and Water Management Survey. Volume 3. Special Studies Part 1. AC-17-SS-1. https://www.nass.usda.gov/Publications/AgCensus/ 2017/Online Resources/Farm and Ranch Irrigation Survey/fris. pdf. (accessed 02/20/2020)

United States Department of Agriculture, National Agricultural Statistics Service (2019b) 2017 Census of agriculture. United States Summary and State Data. Volume 1. Geographic Area Series. Part 51. AC-17-A-51

United States Department of Agriculture National Agricultural Statistics Service (2019c) 2019 California almond forecast. https://www.nass. usda.gov/Statistics_by_State/California/Publications/Specialty_and Other Releases/Almond/Forecast/201905almpd.pdf (accessed 04/02/ 2020)

United States Intelligence Community Assessment (2012) Global water security. ISA 2012-08. https://www.dni.gov/files/documents/ Special\%20Report_ICA\%20Global\%20Water\%20Security.pdf. (accessed 08/28/2020)

Wahl RW (1989) Markets for federal water: subsidies, property rights, and the Bureau of Reclamation. Resources for the Future, Washington, D.C.

Ward FA, Pulido-Velazquez P (2008) Water conservation in irrigation can increase water use. Proc Natl Acad Sci USA 47:18215-18220

Warziniack T, Brown TC (2019) The importance of municipal and agricultural demands in future water shortages in the United States. Environ Res Lett 14:084036 
Weber JG, Wall C, Brown J, Hertz T (2015) Crop prices, agricultural revenues, and the rural economy. Appl Econ Perspect Policy 37(3): 459-476

Welch, H.L., Green, C.T., Rebich, R.A., Barlow, J.R.B., Hicks, M.B. (2010) Unintended consequences of biofuel production: the effects of large-scale crop conversion on water quality and quantity. USGS open file report 2010-1229

Wichelns D (2010) Agricultural water pricing: United States. Hanover College. http://citeseerx.ist.psu.edu/viewdoc/download?doi=10.1.1. 449.3710\&rep=rep1\&type=pdf. Accessed 29 Apr 2021

Winter TC, Harvey JW, Franke OL, Alley WM (1998) Ground water and surface water: a single resource. U.S. Geological Survey circular 1139. Reston, VA
Winters v. United States (1908) 207 U.S. 564:575-77

Wurtsbaugh WA, Miller C, Null SE, DeRose RJ, Wilcock P, Hahnenberger M, Howe F, Moore J (2017) Decline of the world's saline lakes. Nature Geoscience 10:816-821

Zhang T, Lin X, Sassenrath GF (2015) Current irrigation practices in the Central United States reduce drought and extreme heat impacts for maize and soybean, but not for wheat. Sci Total Environ 508:331342. https://doi.org/10.1016/j.scitotenv.2014.12.004

Publisher's Note Springer Nature remains neutral with regard to jurisdictional claims in published maps and institutional affiliations. 